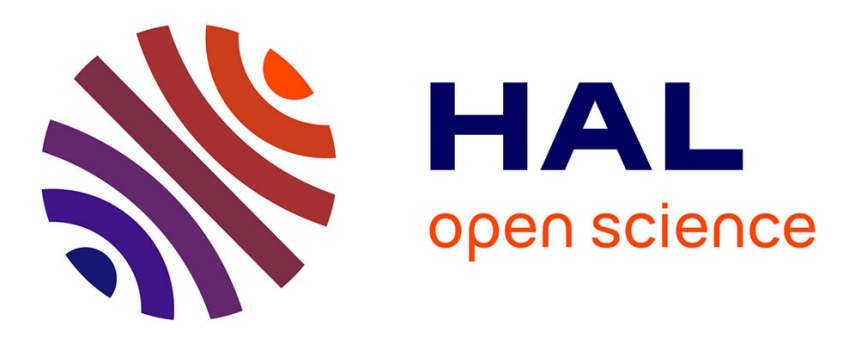

\title{
Biochemical characterization of Extracellular Polymeric Substances extracted from an intertidal mudflat using a cation exchange resin.
}

Guillaume Pierre, Marianne Graber, Francis Orvain, Christine Dupuy, Thierry Maugard

\section{To cite this version:}

Guillaume Pierre, Marianne Graber, Francis Orvain, Christine Dupuy, Thierry Maugard. Biochemical characterization of Extracellular Polymeric Substances extracted from an intertidal mudflat using a cation exchange resin.. Biochemical Systematics and Ecology, 2010, 38, pp.917-923. hal-00652078

\section{HAL Id: hal-00652078 https://hal.science/hal-00652078}

Submitted on 15 Dec 2011

HAL is a multi-disciplinary open access archive for the deposit and dissemination of scientific research documents, whether they are published or not. The documents may come from teaching and research institutions in France or abroad, or from public or private research centers.
L'archive ouverte pluridisciplinaire HAL, est destinée au dépôt et à la diffusion de documents scientifiques de niveau recherche, publiés ou non, émanant des établissements d'enseignement et de recherche français ou étrangers, des laboratoires publics ou privés. 


\section{Biochemical characterization of Extracellular Polymeric Substances}

2 extracted from an intertidal mudflat using a cation exchange resin.

3 Guillaume Pierrea , Marianne Graber ${ }^{\mathrm{a}}$, Francis Orvain ${ }^{\mathrm{b}}$, Christine Dupuy ${ }^{\mathrm{a}}$, Thierry

$4 \quad$ Maugard $^{\mathrm{a}, *}$

a UMR 6250 CNRS - ULR LIENSs. Université de La Rochelle, UFR Sciences, Batiment Marie

7 Curie, avenue Michel Crépeau, 17042 La Rochelle, France.

${ }^{\mathrm{b}}$ UMR 100 IFREMER - UCBN LBBM. Université de Caen Basse-Normandie, esplanade de la

9 Paix, 14032 Caen, France.

* Corresponding author. Tel.: (33) 5464582 77; fax: (33) 546458265.

11 E-mail address: thierry.maugard@univ-lr.fr

\section{ABSTRACT}

The biochemical characterization of Extracellular Polymeric Substances (EPS) excreted in a European intertidal mudflat (Marennes-Oléron Bay) was performed. Experiments were carried out for the first time in situ, by using an improved extraction recently developed. This innovative procedure, using a cation exchange resin (Dowex), allows separating precisely different fractions of EPS, especially pure bound EPS. Moreover, it avoids the contamination of EPS fractions by residual and intracellular polymers, enabling to properly estimate polymeric contents in each fraction. The results were partly similar to conventional results

21 described in the literature and the amount of colloidal carbohydrates $(146 \mu \mathrm{g} / \mathrm{g}$ of dry

22 sediment) extracted by the Dowex method fitted well with different EPS estimation in 
23 European mudflats. Colloidal carbohydrates were essentially composed of glucose (>50\%), a

24 carbon source rapidly consumed by the various communities in the sediment. Pure bound carbohydrates were composed of specific carbohydrates (28\% rhamnose, $22 \%$ xylose). Residual fractions, considered as containing some refractory bound EPS and mostly other internal polymeric substances, presented a more varied composition rich in carbohydrates: galacturonic acid (20\%), mannose (19.5\%), glucose (19\%), arabinose (15\%), xylose (8\%), galactose (7\%).

Keywords: Extracellular compounds, biochemical characterization, biofilm, in situ quantification, benthic ecology

\section{Introduction}

The benthic biofilms which developed during the emerged periods in intertidal mudflats are widely studied for various reasons. Considering an ecological perspective, the main reason is to understand the influence of benthic biofilms in intertidal ecosystems, by analyzing their compositions and their changes, depending on environmental parameters. Numerous studies of the last decades have allowed determining their composition and highlighted the presence of microalgae (microphytobenthos), bacteria and fungi, tangled in a complex mixture of polymeric compounds that they produce (Frølund et al., 1996). These Extracellular Polymeric Substances (EPS) are rich in polysaccharides, proteins, proteoglycans, lipids and many other compounds expressed at different levels (Stoodley et al., 2002; Stal, 2003), related to the location or environmental conditions which affect both food web and primary production of this ecosystem (Underwood and Paterson, 2003). EPS are involved in the mobility system of 
epipelic diatoms (Stal and Défarge, 2005) and can be used as carbon sources by the bacterial community (van Duyl et al., 1999; Hofmann et al., 2009). EPS also affect the microenvironment of biofilms by varying physico-chemical parameters like porosity or mechanical stability of the sediment (Orvain et al., 2003; Perkins et al., 2004; Spears et al., 2008). On the other hand, benthic EPS can present interesting structures and functions, which can be used in many biochemical fields. The extraction of sulfated polysaccharides for medicinal applications is one example (Witvrow et al., 1997). Many works have already proposed extraction protocols allowing the collection of particular EPS, having specific biochemical properties (Stats et al., 1999; de Brouwer et al., 2001; Azerado et al., 2003; Bellinger et al., 2005, Comte et al., 2006). All the data obtained have been each time criticized and authors have agreed that there was no universal extraction method for EPS. Recently, Takahashi et al. (2009) have optimized a protocol for EPS extraction and proposed an innovative method, using a cation exchange resin, to extract cultured diatoms EPS without any contamination by internal compounds. Furthermore, the method allowed the extraction of bound EPS, a fraction poorly studied and heavily contamined in other previous studies (de Brouwer and Stal, 2004; Chiovitti et al., 2004).

The aim of the present investigation was to characterize the biochemical composition of EPS collected from benthic biofilms during emerged periods on a macrotidal bay (MarennesOléron Bay, France), using for the first time in situ the Dowex-resin method (Takahashi et al., 2009).

\section{Methods}

\subsection{Intertidal mudflat samples}

The mud samples used in this study were collected from Marennes-Oléron Bay (Atlantic Coast of France) in February 2008 (winter) at low tide (Fig. 1). Two hours after the beginning 
of the emersion, sediment cores were sampled for three different squares, to take into account spatial heterogeneity. Sediment samples were collected using core diameter of $20 \mathrm{~cm}$, and the top $1 \mathrm{~cm}$ was collected three times and pooled to give a main sediment core, for each square. After sampling, sediment was brought back on from the field by using a watercraft for an immediate EPS extraction on fresh sediments on the upper shore. The colloidal, bound and residual fractions were extracted through the Dowex-resin method then biochemical analyses were performed, all in triplicate.

\subsection{Materials}

Dowex Marathon C, BicinChoninic Acid (BCA) Protein Assay Kit, Azure A, N,Obis(trimethylsilyl)trifluoroacetamide: trimethylchlorosilane (BSTFA: TMCS) (99: 1) were obtained from Sigma-Aldrich. Standard carbohydrates (dextran, dextran sulftate, heparin, fucoïdan, glucose, galactose, rhamnose, fucose, fructose, xylose, arabinose, mannose, myoinositol, glucuronic and galacturonic acid) and a protein standard (Bovine Serum Albumin, BSA) were obtained from Sigma-Aldrich. The DB-1701 J\&W Scientific column (30m, $0.32 \mathrm{~mm}, 1 \mu \mathrm{m})$ for Gas Chromatography-Mass Spectrometry analysis (GC/MS) was obtained from Agilent.

\subsection{EPS Extraction in situ}

The extraction was done immediately after sampling and sediment mixing (Takahashi et al. 2009). $20 \mathrm{~mL}$ of fresh mudflat was mixed with $20 \mathrm{~mL}$ of Artificial Sea Water (ASW 30 Practical Salinity Units) during $1 \mathrm{~h}$ in darkness at $4{ }^{\circ} \mathrm{C}$ and then centrifuged at $3500 \mathrm{~g}$ and $4{ }^{\circ} \mathrm{C}$ for $10 \mathrm{~min}$. The supernatant (a) containing colloidal EPS was collected and stored at $4{ }^{\circ} \mathrm{C} .20$ mL of ASW and $1 \mathrm{~g}$ of activated Dowex (Marathon C, activated in Phosphate Buffer Saline for $1 \mathrm{~h}$ in the dark) was added to the cap (b). The samples were mixed gently at $4^{\circ} \mathrm{C}$ for $1 \mathrm{~h}$ in the dark and then centrifuged at $3500 \mathrm{~g}$ and $4{ }^{\circ} \mathrm{C}$ for $10 \mathrm{~min}$. A supernatant containing the 
bound EPS (c) and a cap containing intracellular and residual polymers (d) were obtained. The cap was then frozen. The residual polymers were extracted from the frozen samples, by sonication at $100 \mathrm{~W}$ for $3 \mathrm{~min}$ on ice after resuspension in $20 \mathrm{~mL}$ in ASW.

For each fraction (colloidal, bound and residual polymers), absolute ethanol at $-20^{\circ} \mathrm{C}$ was added to the sample (a) to obtain a final ethanol concentration of $75 \%(\mathrm{v} / \mathrm{v})$. The solution was gently mixed and stored overnight at $-20^{\circ} \mathrm{C}$. The solution was then centrifuged at $3500 \mathrm{~g}$ and

$4{ }^{\circ} \mathrm{C}$ for 15 min to obtain a supernatant (Low Molecular Weight, LMW fraction) and a cap (High Molecular Weight, HMW fraction). Finally, the fractions were dried under air flow and stored at $-20{ }^{\circ} \mathrm{C}$.

\subsection{EPS Composition}

Total sugar content was determined using the phenol-sulfuric acid assay, developed by Dubois, using glucose as a standard (Dubois et al., 1956). Protein content was determined using the bicinchoninic acid (BCA) assay, using bovine serum albumin (BSA) as a standard (Smith et al., 1985). Uronic acid content was determined using the meta-hydroxydiphenyl method (MHDP), using galacturonic and glucuronic acids as standards (Blumenkrantz and Asboe-Hansen, 1973; Filisetti-Cozzi and Carpita, 1991). The sulfate content was measured by the Azure A (Jaques et al., 1968) and the $\mathrm{Ba} / \mathrm{Cl}_{2}$ gelation method (Craigie et al., 1984), using Dextran sulfate as a standard.

\subsection{Sugar Characterization}

Prior to carbohydrate characterization by GC/MS, EPS fractions were solubilized in $5 \mathrm{~mL}$ of ultra-pure water, dialyzed (6-8 KDa) and freeze-dried (Bellinger et al. 2005). EPS were then dissolved in $2 \mathrm{M} \mathrm{HCl}$ at $50 \mathrm{mg} / \mathrm{mL}$ and heated at $90^{\circ} \mathrm{C}$ for $4 \mathrm{~h}$. The preparation (which contained mostly carbohydrates monomers) was then freeze-dried and stored at $-20^{\circ} \mathrm{C}$. Analysis of the carbohydrate fractions were carried out by GC/MS using a Varian CP-3800 
119 GC/Varian Saturn 2000 (Fig. 2). Operating conditions have been determined and optimized in

120 the laboratory (data not shown). $400 \mu \mathrm{L}$ of pyridine and $400 \mu \mathrm{L}$ of BSTFA: TMCS (99:1) was

121 added to $2 \mathrm{mg}$ of purified polysaccharides. The solution was mixed for $2 \mathrm{~h}$ at room

122 temperature, then injected into a DB-1701 J\&W Scientific column $(30 \mathrm{~m}, 0.32 \mathrm{~mm}, 1 \mu \mathrm{m})$ at

123 a flow of $1 \mathrm{~mL} / \mathrm{min}$. The helium pressure was $8.8 \mathrm{psi}$. The temperature of the injector was set at

$124250{ }^{\circ} \mathrm{C}$. The rise in temperature in the oven was programmed for a first step at $150{ }^{\circ} \mathrm{C}$ for

$1250 \mathrm{~min}$, then an increment of $10^{\circ} \mathrm{C} / \mathrm{min}$ up to $200^{\circ} \mathrm{C}$ with a final step at $200^{\circ} \mathrm{C}$ for $35 \mathrm{~min}$. The 126 ionization was performed by Electronic Impact (EI, $70 \mathrm{eV})$, the trap temperature was set at $127150^{\circ} \mathrm{C}$ and the target ion was fixed at $40-650 \mathrm{~m} / \mathrm{z}$.

\section{3. Results and discussion}

129 3.1. Type and composition of EPS

130 Despite the fact that common practice is to freeze sediments at $-80^{\circ} \mathrm{C}$ to eliminate the

131 consumption of EPS by bacteria, Takahashi's extraction method focus on the use of fresh

132 sediments to avoid cells lysis (Takahashi et al., 2009), which supports other studies

133 concerning the contamination of EPS fractions by internal storage compounds, as glucans,

134 proteins and chrysolaminaran (de Brouwer et al., 2001, Hanlon et al., 2006). The addition of

135 Dowex resin to a classical procedure clearly defines pools of carbohydrates, depending on

136 their properties and localization in the matrix complex (Bellinger et al., 2005; Abdullahi et al., 137 2006).

138 Overall, $1 \mathrm{~g}$ of dry sediment is composed of $1618 \mu \mathrm{g}$ of carbohydrates and $383 \mu \mathrm{g}$ of proteins

139 (Table 1-2). Although this concentration may seem low, EPS are extracted from crude 140 samples. Different authors have shown that natural mudflats samples may contain large 141 quantities of mineral impurities and salt (de Brouwer et al., 2001, Underwood and Paterson, 142 2003). The amounts of carbohydrates were slightly higher than those measured at the same 
143 station in 1998 (Stal and Défarge, 2005). These authors had worked from the first $5 \mathrm{~mm}$ of

144 sediment, which represent more accurately the microphytobenthic biofilm. Our approach (first

$14510 \mathrm{~mm}$ ) could overestimate diatom EPS production due to the contamination from other 146 sediment EPS sources (Perkins et al., 2003).

147 Colloidal fractions were rich in carbohydrates $( \pm 50 / 50 \%$ LMW/HMW) (Table 1-2). LMW 148 colloidal fractions could be compared to the low molecular weight exudates and HMW 149 colloidal fractions EPS extracted by various authors (Abdullahi et al., 2006, Hanlon et al., 150 2006). The total amount of colloidal carbohydrate (neutral carbohydrates and uronic acids) 151 given in Table 1 (146 $\mu \mathrm{g} \cdot \mathrm{g}^{-1}$ sediment) fitted with common results described in literature: 50 152 to $5000 \mu \mathrm{g} \cdot \mathrm{g}^{-1}$ sediment. Similarly, the bound fractions were composed of carbohydrates (87 \% LMW). The total amount of bound carbohydrates was closed to the concentrations of total 154 colloidal carbohydrates $\left( \pm 113 \mu \mathrm{g} \cdot \mathrm{g}^{-1}\right)$. This result would indicate that, in general, the colloidal 155 and bound EPS are produced in close quantities in this benthic ecosystem. However, this 156 amount of bound carbohydrates is lower than other amounts measured for European mudflats 157 and suggests that our fractions were not contamined by residual and internal carbohydrates. 158 Colloidal and bound fractions did not contain proteins, in contrast to many previous works (de 159 Brouwer et al., 2001; Underwood and Paterson, 2003; Hanlon et al., 2006, Hofmann et al., 160 2009). This lack seems to confirm that our EPS fractions were not contamined by residual and 161 internal storage polymers (Staats et al., 2000; Orvain et al., 2003.

162 Finally, the residual fractions were widely extracted compared to the EPS fractions (Table 2) 163 and presented a complex composition especially because of the presence of proteins (22\%) 164 and sulfated components (15\% of the total amount of carbohydrates) (Table 1). Our residual 165 polymers found could be compared to the complex cell wall-associated and the intracellular 166 polymers of diatoms, widely described in the literature (glucan, chrysolaminaran). Otherwise, 
167 these residual fractions must also contain some refractory EPS that were not extracted with 168 the Dowex-resin.

\subsection{Model of Underwood \& Smith}

170 The colloidal EPS quantities measured in the Marennes-Oléron mudflat were compared to the

171 predicted quantities given by the model of Underwood \& Smith, which was used to determine 172 the amount of colloidal carbohydrates produced in European mudflats (Underwood and 173 Smith, 1998). $\log ($ coll. carbohydrates content +1$)=1.40+1.02 \times \log ($ Chl $a$ content +1$)$ $\left\{r^{2}=64.6 \%\right\}$

The model was applied to the concentrations of Chlorophyll $a$ (in average, $21.5 \mu \mathrm{g} \mathrm{Chl} a / \mathrm{g} \mathrm{dw}$ sediment) measured in situ during the sampling campaign. Considering the relationship and the $\mathrm{r}^{2}$, the amount of colloidal carbohydrates extracted by the Dowex-resin was in accordance with the model, suggesting that the Dowex method allowed extracting in full the colloidal

180 EPS.

\subsection{Sugar characterization}

182 GC-MS results indicated that the carbohydrate portions were formed of nine different types of 183 monomer units (Fig. 3), including seven neutral sugars and two uronic acids. The colloidal 184 EPS fractions had a high glucose content $(>50 \%)$, the bound EPS fractions were mainly 185 composed of rhamnose, xylose, glucose, galacturonic acid and the residual polymeric 186 fractions had a more varied composition in monosaccharides, including a greater unknown.

187 The monosaccharide distribution between LMW and HMW of the colloidal fractions was

188 quite similar, although there were a few amount of rhamnose in LMW fractions (Fig. 3, A1189 A2). Colloidal EPS fractions were mainly composed of glucose, which could explain why this 190 fraction is easily consumable by heterotrophic bacteria in the extracellular medium (van Duyl 
et al., 1999; Bellinger et al., 2005; Hofmann et al., 2009). Our results were close to previous

192 works, which showed the predominance of glucose $(50 \%)$, galactose, xylose $(15 \%)$ or 193 galacturonic acid (15\%) in colloidal fractions extracted by the same way (Abdullahi et al., 194 2006; Hanlon et al., 2006). In contrast to previous works where bound fractions were 195 extracted, glucose is not the main saccharide (less than $20 \%$ ) of bound EPS fractions (Fig. 3, 196 B1-B2). The content of specific sugars in these fractions can be better estimated and bound 197 EPS were mainly composed of rhamnose (28\%), xylose (22\%) and galacturonic acid (18\%).

198 The accurate composition of bound EPS, enriched in deoxy and specific sugars, is very 199 important for understanding the functional role of bound EPS. Deoxy sugars can promote 200 biostabilisation of sediments (Zhou et al., 1998; Giroldo et al., 2003) through their surface 201 active properties. Deoxy sugars can also influence the hydrophobic character of EPS, playing 202 a role on the adhesion of EPS to sediment or on the regulation of desiccation and salinity 203 (Spears et al., 2008). However, it was surprising that fucose has not been highlighted although 204 the GC-MS method allowed its detection. It is therefore possible that the lack of fucose was 205 linked to the environmental conditions or the physiological state and the quantity of benthic 206 diatoms forming the benthic biofilm during winter (Stal and Défarge, 2005; Bellinger et al., 207 2009). The presence of inositol (-myo) is significant since no author has highlighted it. 208 Inositol is involved in the structural basis for a number of secondary messengers in eukaryotic 209 cells and is a major growth factor for many-organisms, especially for heterotrophic bacteria. 210 Residual fractions were mainly composed of polysaccharides rich in glucose (derived from $\beta$ 211 1,3-linked glucan or chrysolaminaran) and mannose, rhamnose, xylose (Fig. 3, C1-C2). It is 212 important to note that a portion of these sugars must come from refractory bound EPS.

213 On the whole, our results confirmed the relevance and the effectiveness of Takahashi's 214 method for in situ experiments. Bound fractions were biochemically different from the two 215 other fractions, thanks to the presence of large amounts of deoxy sugars and uronic acids. In 
216 this way, it can be supposed that the levels of rhamnose, mannose or galacturonic acid played 217 a role during the development of the microphytobenthic biofilm by increasing binding forces 218 or enhancing the incorporation of water. The surprising lack of fucose has been correlated to 219 the sampling period. The presence of inositol was detected for a first time in situ. This sugar is 220 commonly used for GC/MS analysis (internal standard) and this could explain why it was not 221 identified as a component of EPS. Significant amounts of this growing factor for bacteria 222 were measured in the colloidal fraction, a fraction known as being a direct nutrient source for 223 the heterotrophic bacteria. Finally, it would be interesting to extract and characterize in situ 224 the same EPS fractions depending on environmental conditions.

\section{Acknowledgements}

This study was supported by the Conseil Général of Charentes-Maritime and the Centre National de la Recherche Scientifique. The field sampling was supported by the French ANR (National Research Agency) through the VASIREMI project "Trophic significance of microbial biofilms in tidal flats" (contract ANR-06-BLAN-0393-01).

\section{References}

231 Abdullahi, A.S., Underwood, G.J.C., Gretz, M.R., 2006. Extracellular matrix assembly in 232 diatoms (Bacillariophyceae). V. Environmental effects on polysaccharide synthesis in the 233 model diatom, Phaeodactylum tricornutum. J. Phycol. 42, 363-378.

234 Azerado, J., Henriques, M., Sillankorva, S., Oliveira, R., 2003. Extraction of exopolymers 235 from biofilm: the protective effect of glutaraldehyde. Water Sci. Technol. 47, 175-179.

236 Bellinger, B.J., Abdullahi, A.S., Gretz, M.R., Underwood, G.J.C., 2005. Biofilm polymers: 237 relationship between carbohydrate biopolymers from estuarine mudflats and unialgal cultures 238 of benthic diatoms. Aquat. Microb. Ecol. 38, 169-180. 
Bellinger, B.J., Underwood, G.J.C., Ziegler, S.E., Gretz, M.R., 2009. Significance of diatom-

240 derived polymers in carbon flow dynamics within estuarine biofilms determined through

241 isotopic enrichment. Aquat. Microb. Ecol. 55, 169-187.

242 Blumenkrantz, N., Asboe-Hansen, G., 1973. New method for quantitative determination of 243 uronic acids. Anal. Biochem. 54, 484-489.

244 de Brouwer, J.F.C., Stal, L.J., 2001. Short-term dynamics in microphytobenthos distribution 245 and associated extracellular carbohydrates in surface sediments of an intertidal mudflat. Mar. 246 Ecol. Prog. Ser. 218, 33-44.

247 de Brouwer, J.F.C., Stal, L.J., 2004. Does warm-water extraction of benthic diatoms yield 248 extracellular polymeric substances or does it extract intracellular chrysolaminaran? Eur. J.

249 Phycol. 39, 129-131.

250 Chiovitti, A., Molino, P., Crawford, S.A., Ten, R., Spurck, T., Wetherbee, R., 2004. The 251 glucans extracted with warm water from diatoms are mainly derived from intracellular 252 chrysolaminaran and not extracellular polysaccharides. Eur. J. Phycol. 39, 117-128.

253 Comte, S., Guibaud, G., Baudu, M., 2006. Relations between extraction protocols for 254 activated sludge extracellular polymeric substances (EPS) and EPS complexation properties 255 Part I. Comparison of the efficiency of eight EPS extraction methods. Enz. Microb. Tech. 38, $256237-245$.

257 Craigie, J.S., Wen, Z.C., van der Meer, J.P., 1984. Interspecific, intraspecific and nutrionally258 determinated variations in the composition of agars from Gracilaria spp. Bot. Mar. 27, 55-61.

259 Dubois, M., Gilles, K.A., Hamilton, J.K., Rebers, P.A., Smith, F., 1956. Colorimetric method 260 for determination of sugars and related substances. Anal. Chem. 28, 350-356. 
261

262

van Duyl, F.C., de Winder, B., Kop, A.J., Wollenzien, U., 1999. Tidal coupling between carbohydrate concentrations and bacterial activities in diatom-inhabited intertidal mudflats. Mar. Ecol. Prog. Ser. 191, 19-32.

Filisetti-Cozzi, T.M., Carpita, N.C., 1991. Measurement of uronic acids without interference from neutral sugars. Anal. Biochem. 197, 157-162.

Frølund, B., Palmgren, R., Keiding, K., Nielsen, P.H., 1996. Extraction of extracellular polymers from activated sludge using a cation exchange resin. Water Res. 30, 1749-1758.

Giroldo, D., Vieira, A.A.H., Paulsen, B.S., 2003. Relative increase of deoxy sugars during microbial degradation of an extracellular polysaccharide released by a tropical freshwater Thalassiosira sp. (Bacillariophyceae). J. Phycol. 39, 1109-1115.

Hanlon, A.R.M., Bellinger, B., Haynes, K., Xiao, G., Hofmann, T.A., Gretz, M.R., Ball, A.S., Osborn, M., Underwood, G.J.C., 2006. Dynamics of extracellular polymeric substances (EPS) production and loss in an estuarine, diatom-dominated, microbial biofilm over a tidal emersion-immersion period. Limnol. Oceanogr. 51, 79-93.

Hofmann, T., Hanlon, A.R.M., Taylor, J.D., Ball, A.S., Osborn, A.M., Underwood, G.J.C., 2009. Dynamics and compositional changes in extracellular carbohydrates in estuarine sediments during degradation. Mar. Ecol. Prog. Ser. 379, 45-58.

Jaques, L.B., Ballieux, R.E., Dietrich, C.P., Kavanagh, L.W., 1968. A microelectrophoresis method for heparin. Can. J. Physiol. Pharmacol. 46, 351-360.

Orvain, F., Galois, R., Barnard, C., Sylvestre, A., Blanchard, G., Sauriau, P.G., 2003. Carbohydrate production in relation to microphytobenthic biofilm development: an integrated approach in a tidal mesocosm. Microb. Ecol. 45, 237-251. 
283

284

285

286

287

288

289

290

291

292

293

294

295

296

297

298

299

300

301

302

303

304

Perkins, R.G., Honeywill, C., Consalvey, M., Austin, H.A., Tolhurst, T.J., Paterson, D.M., 2003. Changes in microphytobenthic chlorophyll $a$ and EPS resulting from sediment compaction due to de-watering: opposing patterns in concentration and content. Cont. Shelf Res. 23, 575-586.

Perkins, R.G., Paterson, D.M., Sun, H., Watson, J., Player, M.A., 2004. Extracellular polymeric substances: quantification and use in erosion experiments. Cont. Shelf Res. 24, 1623-1635.

Smith, P.K., Krohn, R.I., Hermanson, G.T., Mallia, A.K., Gartner, F.H., Provenzano, M.D., Fujimoto, E.K., Goeke, N.M., Olson, B.J., Klenk, D.C., 1985. Measurement of protein using bicinchoninic acid. Anal. Biochem. 150, 76-85.

Spears, B.M., Saunders, J.E., Davidson, I., Paterson, D.M., 2008. Microalgal sediment biostabilisation along a salinity gradient in the Eden Estuary, Scotland: unraveling a paradox. Mar. Freshwater Res. 59, 313-321.

Staats, N., de Winder, B., Stal, L.J., Mur, L.R., 1999. Isolation and characterization of extracellular polysaccharides from the epipelic diatoms Cylindrotheca clostrerium and Navicula salinarum. Eur. J. Phycol. 34, 161-169.

Staats, N., Stal, L.J., Mur, L.R., 2000. Exopolysaccharide production by the epipelic diatom Cylindrotheca clostherium: effects of nutrient conditions. J. Exp. Mar. Biol. Ecol. 249, 13-27.

Stal, L.J., 2003. Microphytobenthos, their extracellular polymeric substances, and the morphogenesis of intertidal sediments. Geomicrobiol. J. 20, 463-478.

Stal, L.J., Défarge, C., 2005. Structure and dynamics of exopolymers in an intertidal diatom biofilm. Geomicrobiol. J. 22, 341-352. 
305 Stoodley, P., Sauer, K., Davies, D.G., Costerton, J.W., 2002. Biofilms as complex 306 differentiated communities. Annu. Rev. Microbiol. 56, 187-209.

307 Takahashi, E., Ledauphin, J., Goux, D., Orvain, F., 2009. Optimizing extraction of 308 extracellular polymeric substances (EPS) from benthic diatoms: comparison of the efficiency 309 of six EPS extraction methods. Mar. Freshwater Res. 60, 1201-1210.

310 Underwood, G.J.C., Smith, D.J., 1998. Predicting epipelic diatom exopolymer concentrations 311 in intertidal sediments from sediment chl. $a$. Microb. Ecol. 35, 116-125.

312 Underwood, G.J.C., Paterson, D.M., 2003. The importance of extracellular carbohydrate 313 production by marine epipelic diatoms. Adv. Bot. Res. 40, 184-240.

314 Witvrouw, M., De Clercq, E., 1997. Sulfated polysaccharides extracted from sea algae as 315 potential antiviral drugs. Gen. Pharmac. 29, 497-511.

316 Zhou, J., Mopper, K., Passow, U., 1998. The role of surface-active carbohydrates in the 317 formation of transparent exopolymer particles by bubble adsorption of seawater. Limnol. 318 Oceanogr. 43, 1860-1871. 
320 Table 1 Composition ( $\mu \mathrm{g} / \mathrm{g}$ of dry sediment) of the different fractions extracted by the Dowex

321 method from the Marennes-Oléron mudflat.

\begin{tabular}{lcccc}
\hline Fraction & $\begin{array}{c}\text { Neutral carbohydrate } \\
\text { content }\end{array}$ & $\begin{array}{c}\text { Uronic acid } \\
\text { content }\end{array}$ & Sulfate content & $\begin{array}{c}\text { Protein } \\
\text { content }\end{array}$ \\
\hline LMW colloidal & $59 \pm 8$ & $23 \pm 9$ & 0 & 0 \\
HMW colloidal & $57 \pm 16$ & $7 \pm 2$ & 0 & 0 \\
\hline LMW bound & $76 \pm 8$ & $22 \pm 10$ & 0 & 0 \\
HMW bound & $11 \pm 2$ & $4 \pm 2$ & 0 & 0 \\
\hline LMW residual & $413 \pm 79$ & $112 \pm 38$ & 0 & $180 \pm 72$ \\
HMW residual & $530 \pm 155$ & $304 \pm 172$ & $204 \pm 66$ & $203 \pm 55$
\end{tabular}

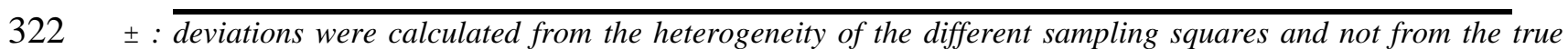

323 replicates of the biochemical analysis $(<5 \%)$ 
325 Table 2 Distribution of carbohydrates in the three fractions of EPS.

\begin{tabular}{lccc}
\hline$\%(\mathrm{w} / \mathrm{w})$ & Fraction Ratio & $\begin{array}{c}\text { Low Molecular } \\
\text { Weight }\end{array}$ & $\begin{array}{c}\text { High Molecular } \\
\text { Weight }\end{array}$ \\
\hline Colloidal carbohydrates & 9 & 56 & 44 \\
Bound carbohydrates & 7 & 87 & 13 \\
Residual carbohydrates & 84 & 39 & 61 \\
Total carbohydrates & $100^{*}$ & 43 & 57 \\
\hline
\end{tabular}

$326 *(1618 \mu \mathrm{g} / \mathrm{g}$ of dry sediment $)$ 
328 Fig. 1. Station where samples of surficial intertidal sediment were collected, two hours after 329 the beginning of emerged period.

330 Fig. 2. GC-MS chromatogram of carbohydrates detected in an HMW bound fraction. 331 Ionization: Electronic Impact (EI). Target ion: 40-650 m/z.

332 Fig. 3. Monosaccharide composition of the different EPS fractions collected on the Marennes333 Oléron mudflat (\% of the carbohydrate content) after 2 hours of emersion. Ionization: 334 Electronic Impact (EI). Target ion: 40-650 m/z. The variability within true sample replicate 335 was less than 5\%. (White): Unknown, undetermined on GC/MS. 


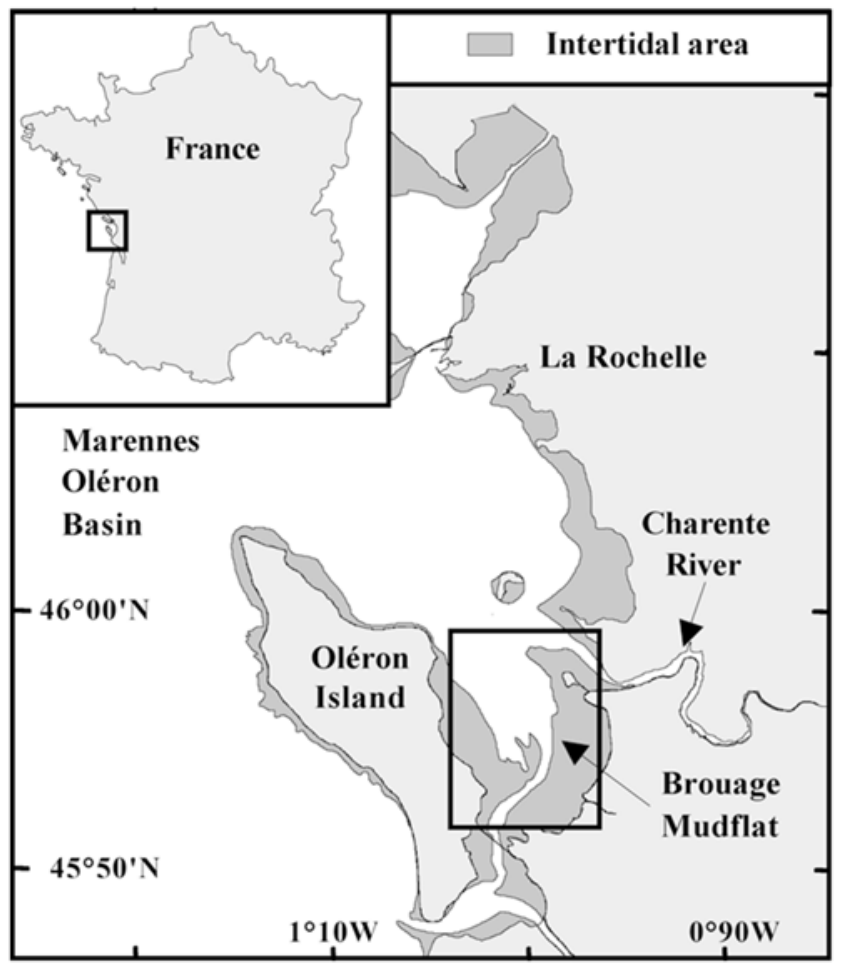

338

FIGURE 1 


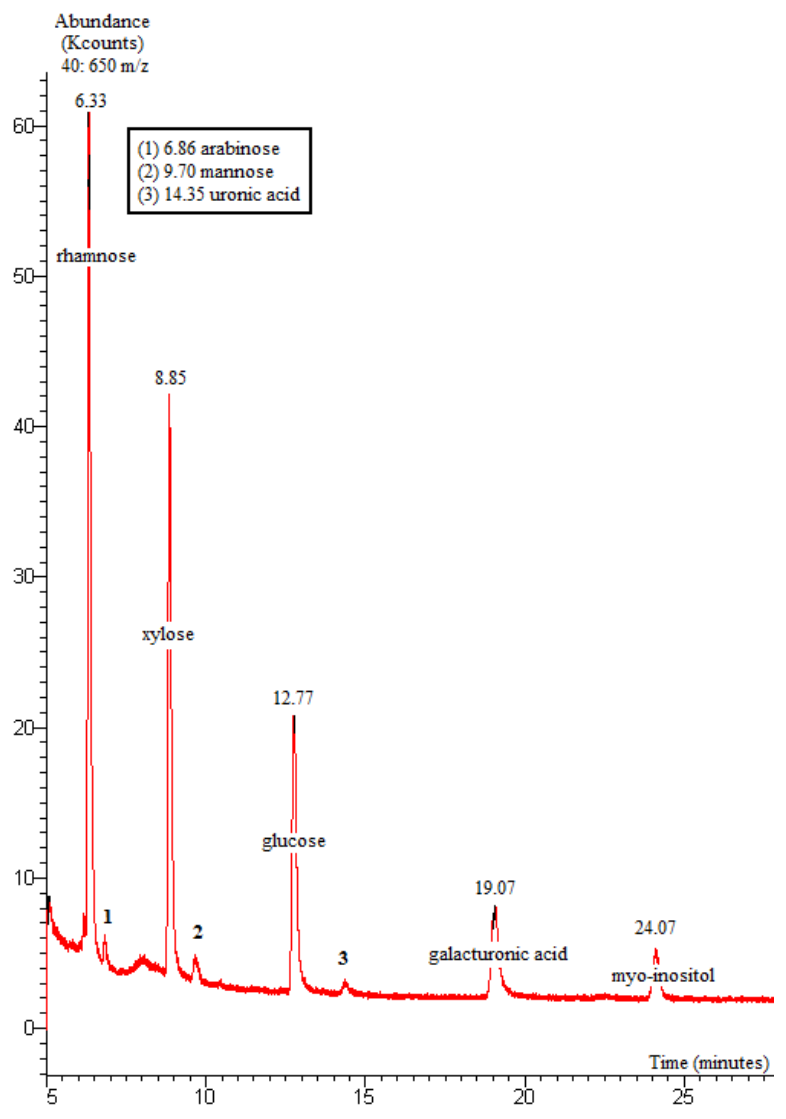

343

FIGURE 2 

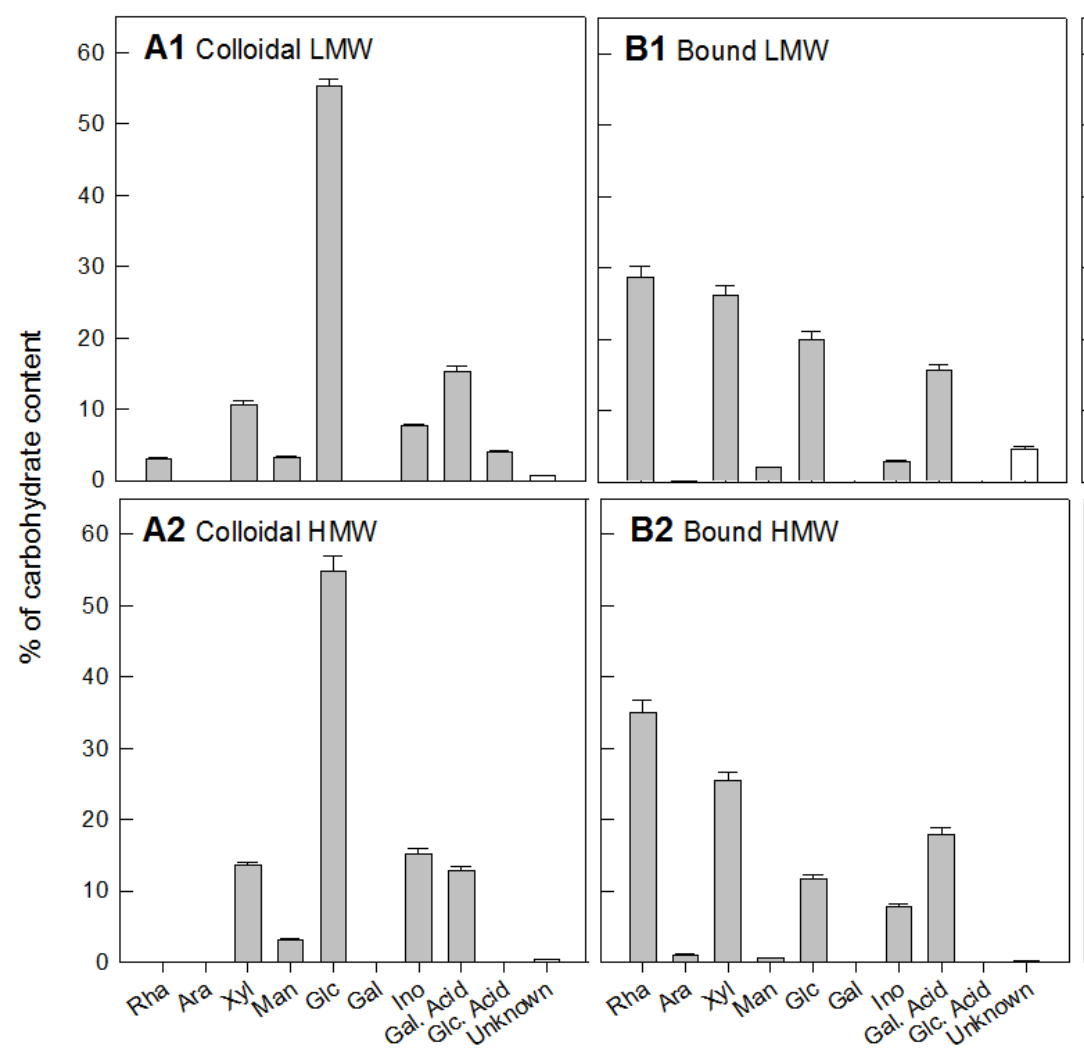

C1 Residual LMW

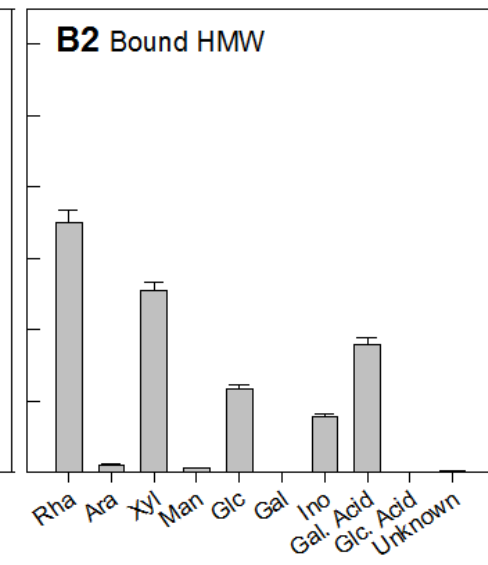

C2 Residual HMW

347

FIGURE 3 